\title{
Kualitas Minyak Kelapa Hasil Fermentasi Saccharomyces cereviceae
}

\author{
The quality of coconut oil produced by Saccharomyces cereviceae fermentation
}

\author{
Exsyupransia Mursyanti
}

Fakultas Biologi, Universitas Atma Jaya Yogyakarta, Jl. Babarsari 44 Yogyakarta 55281

E-mail: santi_em@mail.uajy.ac.id

\begin{abstract}
One aspects of utilization of coconut fruit is its palm oil. Traditionally coconut oil was made by "klentik" method, which was time and energy consuming. The important thing in the production of coconut oil from its xanthan is the separation of protein from oil. One of separation methods is by creating low $\mathrm{pH}$ (acid) condition that is near to protein isoelectric point. This research objective was to determine the potency of Saccharomyces cereviceae, that has an optimum growth $\mathrm{pH}$ within the range of protein isoelectric point, to produce coconut oil. Three isolates of Saccharomyces were used, i.e. isolate A that was coming from alcohol industry ( $S$. cereviceae strain Kyowa), isolate $B$ that was natural type (isolated from fruits), and isolate $\mathrm{C}$ that was $\mathrm{S}$. cereviceae in the form of powder (commercial isolate, Saf-instant). Coconut xanthan used in the research was prepared from old coconut fruits. Research stages including pure culture test of $S$. cereviceae, starter preparation, xanthan production, fermentation process, oil separation and heating. Quantitative and qualitative analyses were done for oil rendement, water content, free-fatty acid concentration, saponification number, iod number, and organoleptic test (color and aroma). The results showed that the quality of coconut oil produced by fermentation process was better than traditional way in term of rendement value, water content, saponification number, and iod number. This was supported also by organoleptic test that aroma and color of coconut oil from fermentation were more preferred by the panelists. Furthermore, the quality of oil produced by $S$. cereviceae fulfilled the standart stated by the Indonesian Department of Commerce (SII-1976) except for saponification number.
\end{abstract}

Keyword: coconut oil, Saccharomyces cereviceae, fermentation

Diterima : 04 Agustus 2005, disetujui : 03 September 2005

\section{Pendahuluan}

Indonesia merupakan salah satu negara penghasil kelapa yang mempunyai areal lahan tanaman kelapa mencapai 3.334.000 hektar (Anonim, 1990). Hal ini membuktikan bahwa Indonesia adalah negara produsen kelapa utama di dunia (Anonim, 2004).

Salah satu pemanfaatan tanaman kelapa adalah daging buahnya yang digunakan untuk pembuatan minyak (Buda, 1981). Minyak kelapa mengadung asam laurat, yang termasuk asam lemak rantai menengah (hampir setara dengan air susu ibu) sebesar 50-57\% (Sibuea,
2004), mengandung vitamin E dan bermacammacam enzim (Anonim, 2004; Maria, 2005), serta mempunyai titik leleh $76{ }^{\circ} \mathrm{C}$ (Eniq, 2005).

Pembuatan minyak dari daging kelapa yang sering dilakukan oleh masyarakat Indonesia adalah dengan cara basah. Pembuatan minyak kelapa cara basah dikenal dua macam cara yaitu cara klentik dan cara fermentasi. Pada pembuatan minyak cara klentik atau tradisonal, minyak diperoleh dengan cara memanaskan santan sampai beberapa jam sampai diperoleh minyak dan blondo, sedangkan pembuatan minyak secara fermentasi menggunakan jasa mikrobia untuk 
membuat minyak dan blondo dari santan kelapa (Setiaji dan Sasmita, 1987; Anggraheni dan Dhalimi, 1993). Dasar pembuatan minyak cara fermentasi yaitu adanya penggunaan mikrobia yang menghasilkan suasana asam pada mediumnya sehingga lapisan pelindung protein dapat rusak dan minyak dapat terpisah (Suhardiman, 1994). Beberapa keuntungan dari cara fermentasi apabila dibandingkan dengan cara klentik, yaitu lebih hemat bahan bakar dan tenaga untuk mengolah, hasil minyak yang lebih tinggi, protein sebagai hasil samping (blondo) dapat dimanfaatkan untuk keperluan lain, minyak yang dihasilkan dapat langsung dipergunakan tanpa proses pemurnian.

Mikrobia alternatif yang perlu dikembangkan dalam pembuatan minyak kelapa adalah mikrobia yang mudah didapat dan umum digunakan, mempunyai daya adaptasi terhadap lingkungan yang tinggi, mampu tumbuh dengan cepat (Tortora et al., 2001) dan termasuk golongan Generally Recognized as Safe (GRASS). Sifat lain yang penting dalam pembuatan minyak adalah mempunyai kemampuan memisahkan minyak dari protein santan. Oleh karena itu, penelitian ini mengkaji potensi $S$. cereviceae dalam memisahkan minyak dari protein santan sehingga diharapkan akan menghasilkan minyak kelapa yang mempunyai kualitas yang lebih baik daripada minyak klentik.

\section{Metode Penelitian}

\section{Waktu, Tempat dan Bahan Penelitian}

Penelitian dilakukan di laboratorium Instruksional II dan Laboratorium Biopangan dan Bioindustri, Fakultas Biologi, Universitas Atma Jaya Yogyakarta. Penelitian dilakukan pada bulan Agustus sampai November 2003.

Isolat $S$. cereviceae yang digunakan sebanyak tiga macam isolat yaitu isolat A berasal dari industri alkohol ( $S$. cereviceae strain Kyowa), Isolat B yaitu tipe alami (yang langsung diisolasi dari buah) dan Isolat $\mathrm{C}$ yaitu S. cereviceae dalam bentuk powder (kemasan yang diperdagangkan, Saf-instant). Santan yang digunakan berasal dari parutan daging buah kelapa tua. Medium yang digunakan adalah medium ekstrak taoge cair dan padat, medium irisan wortel. Senyawa kimia yang digunakan adalah senyawa kimia untuk analisis kuantitatif dan kualitatif minyak.

\section{Cara penelitian}

Tahapan penelitian yang dilakukan meliputi tahap uji kemurnian dan pembuatan starter, tahap penentuan fase pertumbuhan logaritmik $S$. cereviceae dan pengukuran $\mathrm{pH}$, tahap pembuatan santan, proses fermentasi dan pemisahan minyak, dan analisis kuantitatif, kualitatif dan organoleptik minyak kelapa. Data yang diperoleh selanjutnya diperbandingkan dengan kualitas standart yang dipersyaratkan oleh SNI.

\section{Tahap uji kemurnian dan pembuatan starter}

Pada tahap ini dilakukan pengamatan koloni pada medium ekstrak taoge padat, pengamatan bentuk sel dengan pengecatan metilen blue, pengamatan spora dengan menggunakan medium irisan wortel. Untuk pembuatan starter, biakan $S$. cereviceae dari tiga tipe isolat diambil 1 ose dan ditumbuhkan dalam medium ektrak taoge cair sebanyak 25 ml. Selanjutnya diinkubasi pada suhu kamar selama 24 jam.

\section{Penentuan fase logaritmik $S$. cereviceae dan pengukuran $\mathrm{pH}$}

Terjadinya fase logaritmik dapat ditentukan berdasarkan pola pertumbuhan. Metode yang digunakan adalah turbidimetri pada panjang gelombang $600 \mathrm{~nm}$. Pengukuran $\mathrm{pH}$ dilakukan dengan $\mathrm{pH}$ meter. Setiap dua jam diamati pertumbuhannya dan $\mathrm{pH}$ medium, selama 24 jam inkubasi.

\section{Pembuatan santan}

Daging kelapa yang sudah tua diparut dan dibuat santan dengan menggunakan air hangat $\left(50^{\circ} \mathrm{C}\right)$. Pembuatan santan dilakukan dengan mengekstraksi parutan kelapa sebanyak $2 \mathrm{x}$ dengan perbandingan parutan kelapa dan air adalah 1:1 (b/b). Selanjutnya, santan dibiarkan beberapa saat sampai bagian krim dan bagian skimnya membentuk lapisan yang terpisah. Krim yang terbentuk digunakan untuk 
membuat minyak secara tradisional (sebagai kontrol) dan minyak secara fermentasi.

\section{Proses fermentasi dan pemisahan minyak}

Seratus ml krim santan dimasukkan ke dalam tabung pisah dan ditambah starter (dari masing-masing isolat) sebanyak $1 / 3$ bagian. Kemudian ditutup dan diinkubasi selama 12 jam pada suhu kamar. Setelah masa inkubasi, akan terlihat lapisan minyak (atas), lapisan protein dan air. Campuran minyak dan protein selanjutnya dipanaskan pada suhu $100^{\circ} \mathrm{C}$ sampai minyak terpisah dari proteinnya (blondo).

\section{Analisis Kuantitatif, Kualitatif dan Organoleptik Minyak}

Analisis kuantitatif dan kualitatif meliputi rendemen minyak (Muchtar et al., 1981), kadar air, kadar asam lemak bebas, bilangan penyabunan (Ketaren, 1986), bilangan yodium (Ketaren, 1986), bilangan peroksida (Ketaren, 1986). Analisis organoleptik meliputi warna dan aroma menggunakan metode uji penerimaan atau kesukaan (hedonik) dengan menggunakan 25 orang responden yang belum terlatih (Gusmalini et al., 1997). Skoring yang digunakan adalah :

$$
\begin{aligned}
& 9=\text { amat sangat senang } \\
& 8=\text { sangat senang } \\
& 7=\text { senang } \\
& 6=\text { agak senang } \\
& 5=\text { netral } \\
& 4=\text { agak tidak senang } \\
& 3=\text { tidak senang } \\
& 2=\text { sangat tidak senang } \\
& 1=\text { amat sangat tidak senang }
\end{aligned}
$$

\section{Hasil dan Pembahasan}

Santan yang berasal dari parutan daging kelapa yang telah tua akan berwarna putih kental seperti susu. Santan ini apabila diinokulasi dengan $S$. cereviceae dengan waktu inkubasi selama 12 jam didapatkan lapisan dipermukaan yang sangat kental seperti krim yang banyak mengandung minyak. Penghasilan minyak dalam penelitian ini menggunakan krim santan saja yang dipanaskan dalam waktu yang relatif sangat singkat ( \pm 8 menit).

\section{Hasil Uji kemurnian S. cerevisiae}

Karakterisasi terhadap tiga isolat $S$. cerevisiae, yaitu isolat $\mathrm{A}, \mathrm{B}, \mathrm{C}$ yang digunakan untuk penelitian ini seperti yang disajikan pada Tabel 1. Ciri-ciri yang ditunjukkan yang meliputi bentuk sel yang uniseluler (Simmons, 2005), bentuk koloni, warna koloni, ukuran relatif koloni dan bentuk spora sesuai dengan pernyataan Yarrow (1994) dan Fardiaz (1992).

\section{Pola Pertumbuhan dan Profil pH $S$. cereviceae pada Medium PGY}

Pembuatan pola pertumbuhan $S$. cereviceae pada medium PGY dengan sistem kultur sekali unduh perlu dilakukan untuk mengetahui terjadinya fase logaritmik. Menurut Tortora et al., (2001) dan Brock et al., (1997), fase pertumbuhan dimana jumlah mikrobia mencapai maksimum terjadi pada fase logaritmik akhir. Hal ini dikarenakan nutrisi maupun oksigen masih banyak tersedia dalam medium pertumbuhan sehingga memacu sel melakukan glikolisis untuk menghasilkan energi yang digunakan untuk pembelahan biner secara cepat (Lloyd, 2005).

Tabel 1. Bentuk sel, koloni dan spora $S$. cereviceae isolat A, B dan C

\begin{tabular}{cllllc}
\hline \hline $\begin{array}{c}\text { Macam } \\
\text { Isolat }\end{array}$ & Bentuk sel & Bentuk koloni & Warna koloni & $\begin{array}{c}\text { Ukuran relatif } \\
\text { koloni }\end{array}$ & Bentuk spora \\
\hline \hline A & $\begin{array}{l}\text { Oval agak } \\
\text { lonjong }\end{array}$ & $\begin{array}{l}\text { circulair, elevasi low convex, tepi } \\
\text { entire }\end{array}$ & Putih & Paling kecil & $\begin{array}{l}\text { Oval terdapat } \\
\text { dalam sel }\end{array}$ \\
B & $\begin{array}{l}\text { Oval agak } \\
\text { circulair, elevasi low convex, tepi } \\
\text { lonjong }\end{array}$ & Putih & Paling besar & $\begin{array}{l}\text { Oval terdapat } \\
\text { dalam sel }\end{array}$ \\
C & $\begin{array}{l}\text { Oval agak } \\
\text { circulair, elevasi low convex, tepi } \\
\text { lonjong }\end{array}$ & Putih agak krem & Sedang & $\begin{array}{l}\text { Oval terdapat } \\
\text { dalam sel }\end{array}$ \\
\hline \hline
\end{tabular}


Pola pertumbuhan dari ke-3 macam isolat $S$. cereviceae (Gambar 1) menunjukkan tiga tahap pertumbuhan yaitu tahap adaptasi (24 jam inkubasi), tahap logaritmik (4-12 jam inkubasi) dan tahap stasioner yang dimulai dari jam ke-12 inkubasi. Puncak tahap logaritmik (biomasa paling banyak) ditemukan pada jam inkubasi ke-12. Perbedaan yang tampak diperlihatkan oleh isolat A, yaitu memperlihatkan fase adaptasi yang paling lama (4 jam inkubasi) dan jumlah biomasa sel (ditunjukkan dengan nilai OD yang lebih rendah) yang paling rendah. Hal ini menandakan bahwa isolat A mempunyai kecepatan pertumbuhan yang rendah dibandingkan dengan isolat B dan C. Menurut Cruger and Crueger (1990), mikrobia yang digunakan untuk komersial atau industri adalah strain alami yang sudah dilakukan strain development, misalnya sudah dimutasi atau direkayasa sehingga menjadi strain yang unggul.

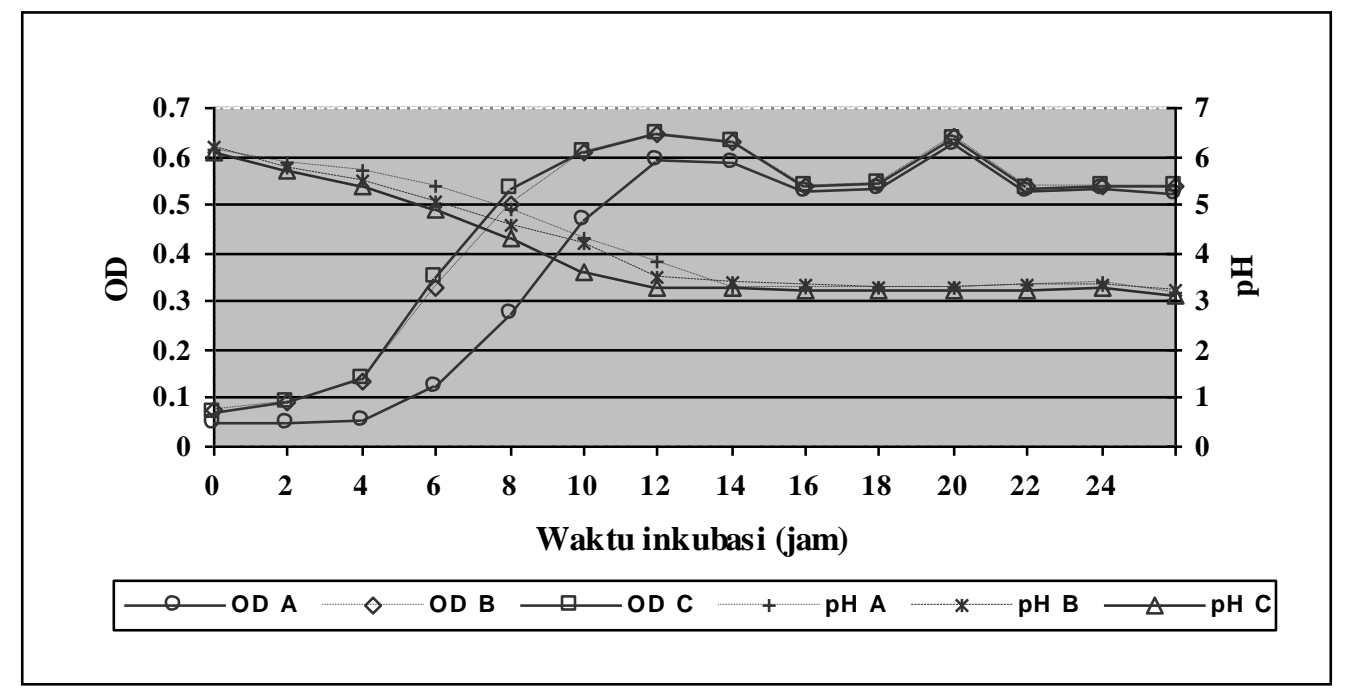

Gambar 1. Pola pertumbuhan (OD) dan profil $\mathrm{pH}$ medium selama 24 jam inkubasi pada kultur sekali unduh $S$. cereviceae isolat A, B, dan C

Saccharomyces cerevisiae mempunyai kisaran pH pertumbuhan antara 4-4,5 (Fardiaz,1992). Berdasarkan Gambar 1, profil $\mathrm{pH}$ medium menunjukkan grafik yang menurun. Derajat keasaman pada awal inkubasi berkisar 6,20, sedangkan akhir inkubasi (jam ke 24) berkisar 3,28 . Derajat keasaman yang mendekati titik isoelektris protein $(\mathrm{pH} \mathrm{3,8-3,9)}$ dicapai pada waktu inkubasi 12 jam. Kurva $\mathrm{pH}$ mulai menurun disebabkan karena $S$. cerevisiae melakukan perombakan karbohidrat terutama sukrosa dalam medium menjadi alkohol dan asam-asam organik, antara lain asam sitrat, asam asetat, asam glukonat (Gill et al., 1996). Berdasarkan nilai $\mathrm{pH}$ yang mendekati titik isoelektris protein dan jumlah biomasa sel yang paling banyak maka waktu inkubasi yang tepat, setelah inokulasi santan dengan $S$. cereviceae, untuk menghasilkan minyak dari krim santan adalah 12 jam inkubasi.

\section{Uji Kuantitas dan Kualitas Minyak Hasil Fermentasi}

Hasil yang diperoleh dari uji kuantitas minyak yang meliputi rendemen, uji kualitas minyak yang meliputi kadar air, bilangan penyabunan bilangan asam lemak bebas, bilangan iodium, dan uji organoleptik yang meliputi warna dan aroma, dapat dilihat pada Tabel 2.

Menurut Muchtar et al., (1981), jumlah rendemen minyak juga berhubungan dengan $\mathrm{pH}$ santan, bila $\mathrm{pH}$ santan berada di atas atau di bawah $\mathrm{pH}$ isoelektris protein maka pemecahan emulsi santan serta pengendapan protein akan lambat. 
Tabel 2. Hasil uji kuantitas, kualitas dan organoleptik minyak kelapa hasil fermentasi pada ke-3 isolat $S$. cereviceae yang digunakan dalam penelitian

\begin{tabular}{lccccc}
\hline \hline \multicolumn{1}{c}{ Parameter } & Tradisional (Kontrol) & Isolat A & Isolat B & Isolat C & Standart mutu (SII)* \\
\hline Rendemen (\%) & 14,144 & 18,464 & 20,403 & 20,299 & - \\
Bilangan iodium & 7,855 & 11,877 & 10,321 & 15,387 & $7,5-10,5$ \\
Kadar air (\%) & 0,347 & 0,199 & 0,332 & 0,282 & Maks 0,5 \\
Bilangan asam lemak bebas & 0,076 & 0,206 & 0,189 & 0,155 & Maks 6,0 \\
Bilangan penyabunan & 244,904 & 241,736 & 246,377 & 240,923 & $250-265$ \\
Warna & 5,973 & 6,373 & 5,800 & 5,773 & Normal \\
Aroma & 5,840 & 5,760 & 5,760 & 5,747 & Normal \\
\hline \hline
\end{tabular}

Berdasarkan Tabel 2 dan Gambar 1, rendemen minyak cara tradisional (kontrol) rendah. Hal ini dikarenakan pemisahan minyak dari emulsi santan hanya dengan cara pemanasan sehingga minyak belum seluruhnya terekstrak. Rendemen minyak cara fermentasi cenderung lebih tinggi, paling tinggi dihasilkan dari perlakuan penggunaan $S$. cereviceae isolat $\mathrm{B}$, hal ini dikarenakan adanya asam yang memecah emulsi krim santan dan menyebabkan penurunan $\mathrm{pH}$ santan. Menurut Setiaji dan Sasmita (1987), santan merupakan emulsi minyak dalam air dengan protein sebagai zat pemantap emulsinya. Penurunan pH sebagai hasil akhir fermentasi akan memecah protein sehingga minyak dan air akan terpisah.

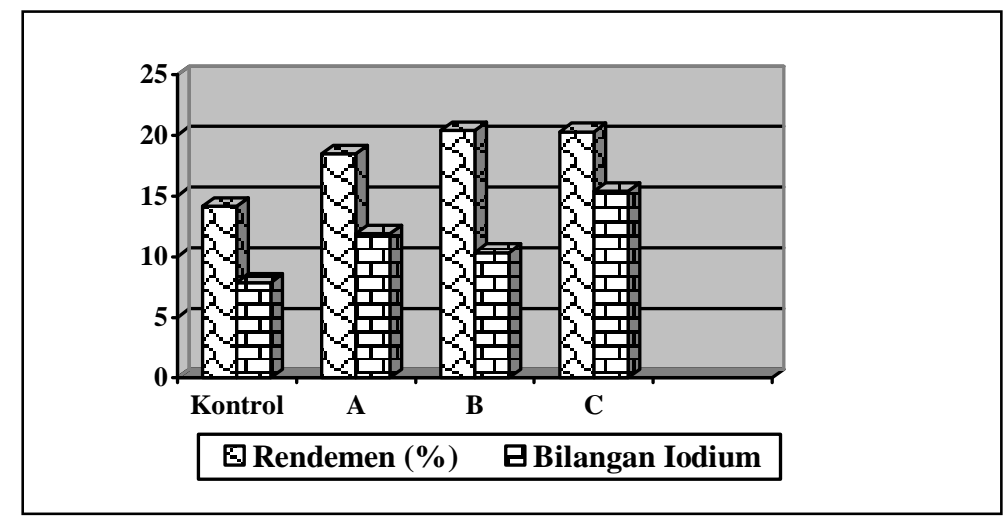

Gambar 2. Rendemen dan Bilangan Iodium pada minyak tradisional (kontrol) dan hasil fermentasi ke-3 isolat $S$. cereviceae (A, $\mathrm{B}$ dan $\mathrm{C})$

Bilangan iodium diperlukan untuk mengetahui tingkat ketidakjenuhan minyak. Jika bilangan iodium minyak makin tinggi berarti minyak tersebut semakin banyak mengandung banyak asam lemak tak jenuh. Minyak kelapa masuk dalam golongan minyak laurat, yang sedikit mengandung asam lemak tidak jenuh sehingga sifat ketidakjenuhan rendah (Ketaren, 1986). Berdasarkan Gambar 1 dapat dilihat bahwa bilangan iodium minyak yang dihasilkan secara tradisional dan cara fermentasi dengan isolat $B$ adalah sesuai dengan bilangan iodium yang dipersyaratkan $(7,5-10,5)$, sedangkan minyak dari perlakuan menggunakan isolat $\mathrm{A}$ dan $\mathrm{C}$ lebih tinggi dari yang dipersyaratkan.

Kadar air dari minyak yang dihasilkan dari semua perlakuan menunjukkan kadar air yang lebih rendah dari yang dipersyaratkan (Tabel 2). Kadar air yang paling rendah dihasilkan dari perlakuan menggunakan isolat A sedangkan paling tinggi dihasilkan dari perlakuan kontrol (Gambar 2). Kadar air minyak tidak berhubungan langsung dengan proses fermentasi tetapi mempunyai hubungan langsung dengan pemanasan yang dilakukan terhadap minyak setelah proses fermentasi (Tazar et al., 1998). Minyak masih memiliki kadar air tinggi karena masih ada air yang Biota Vol. X (3), Oktober 2005 
terikat pada minyak akibat pemisahan yang tidak sempurna. Jika kadar air dalam minyak tinggi menunjukkan kualitas minyak rendah karena minyak akan mudah mengalami ketengikan akibat hidrolisis (Hamdan, 1991).

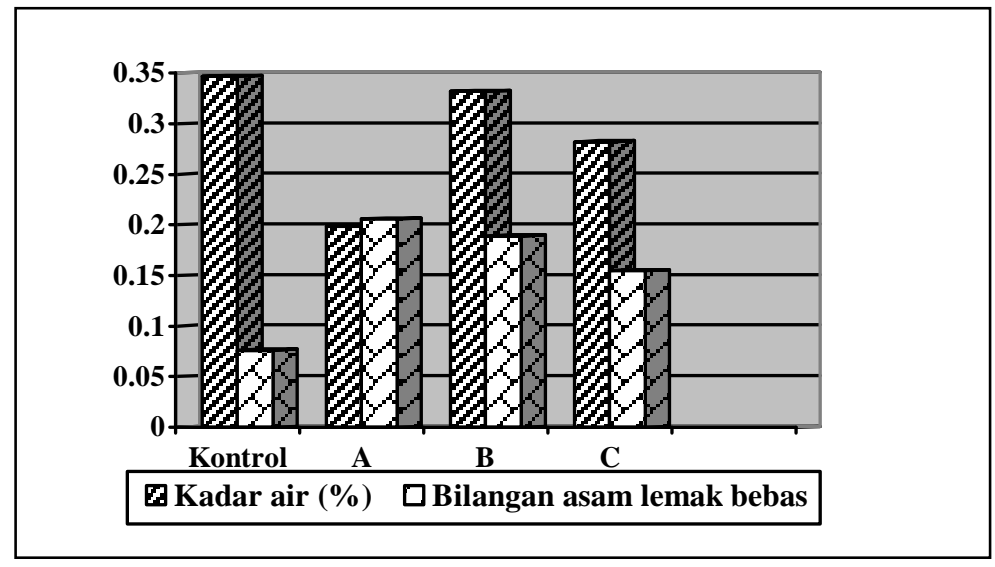

Gambar 3. Kadar air dan Bilangan asam lemak bebas pada minyak tradisional (kontrol) dan hasil fermentasi dari Ke-3 isolat $S$. cereviceae (A, B dan C).

Bilangan asam lemak bebas yang tinggi menunjukkan asam lemak bebas yang dihasilkan dari proses hidrolisis minyak cukup banyak. Makin tinggi bilangan asam lemak bebas maka makin rendah kualitasnya. Berdasarkan pengamatan terhadap kandungan asam lemak bebas pada minyak yang dihasilkan (Gambar 2) baik secara tradisional maupun fermentasi menunjukkan bahwa kandungan asam lemak bebasnya masih rendah dari yang dipersyaratkan (Maksimum enam). Hal ini menunjukkan bahwa minyak yang dihasilkan dari semua perlakuan masih memenuhi kualitas yang dipersyaratkan untuk asam lemak bebas.

Bilangan penyabunan dipengaruhi oleh adanya senyawa yang tidak tersabunkan dalam minyak. Apabila bilangan penyabunan minyak tinggi maka minyak tersebut banyak mengandung senyawa yang tidak tersabunkan (Ketaren, 1986). Hasil pengamatan terhadap bilangan penyabunan (Gambar 3) menunjukkan bahwa semua minyak hasil fermentasi maupun tradisional menunjukkan angka penyabunan yang lebih rendah dari yang dipersyaratkan. Angka penyabunan yang paling tinggi terdapat pada minyak dengan perlakuan menggunakan S. cereviceae isolat B, yaitu 246,377 (yang dipersyaratkan 250-265), sedangkan yang paling rendah adalah minyak dengan perlakuan menggunakan $S$. cereviceae isolat $\mathrm{C}$, yaitu 240,923 .

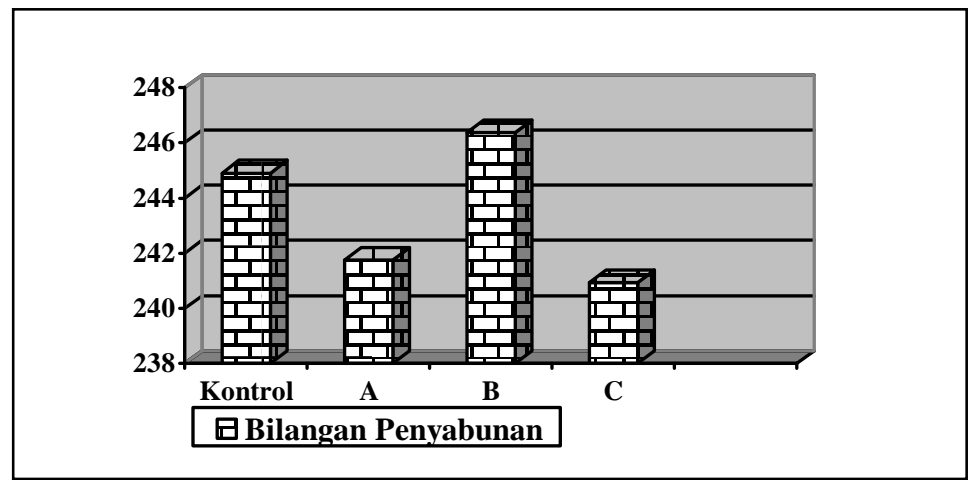

Gambar 4. Bilangan penyabunan pada minyak tradisional (kontrol) dan hasil fermentasi dari Ke-3 isolat $S$. cereviceae (A, $\mathrm{B}$ dan C) 
Menurut Ketaren (1986) dan Tazar et al., (1998), besarnya bilangan penyabunan tergantung pada berat molekul trigliserida penyusun minyak. Berat molekul minyak tinggi menunjukkan rantai hidrokarbon semakin panjang. Hal ini menunjukkan kualitas minyak yang semakin baik karena titik bekunya rendah sehingga tidak mudah menggumpal dan tidak mudah teroksidasi oleh panas (Ketaren, 1986).

Uji organoleptik dilakukan untuk mengetahui tingkat penerimaan konsumen terhadap warna dan aroma minyak. Warna minyak cenderung bening kekuningan disebabkan oleh adanya pigmen karoten yang terdapat pada kelapa (Ketaren, 1986). Minyak yang berwarna kuning lebih gelap disebabkan karena reaksi gula-gula pereduksi dengan asam amino yang terdapat pada emulsi santan selama pemanasan sehingga terjadi reaksi browning non enzimatis (Gusmalini et al., 1997). Aroma pada minyak fermentasi dan minyak cara tradisional khas karena adanya nonil metil keton yang merupakan senyawa pembentuk aroma (Ketaren, 1986).

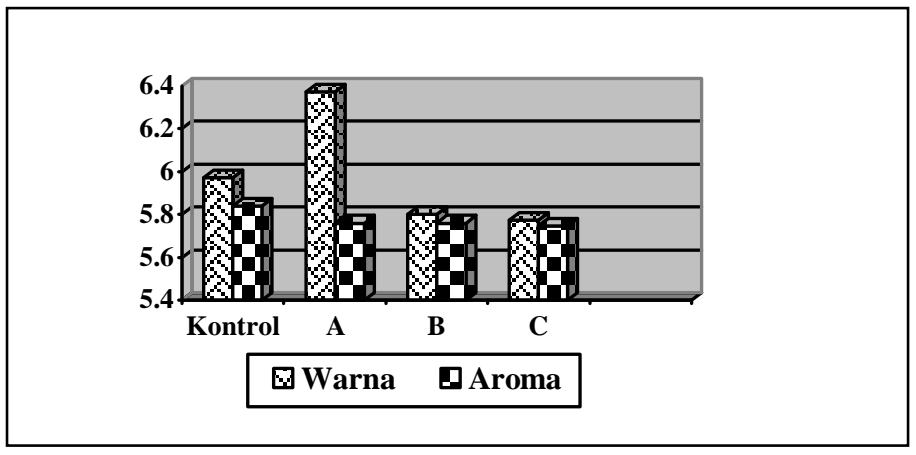

Gambar 5. Warna dan aroma minyak tradisional (kontrol) dan hasil fermentasi $S$. cereviceae dari Ke-3 isolat $S$. cereviceae (A, B dan C)

Berdasarkan pengamatan terhadap warna dan aroma minyak (Gambar 5) menunjukkan bahwa warna minyak yang paling disukai adalah minyak dengan perlakuan isolat $\mathrm{A}$ (skor 6,37), sedangkan aroma menunjukkan konsumen menyukai semua minyak yang dihasilkan dari semua perlakuan.

\section{Kesimpulan dan Saran}

Kesimpulan yang dapat diambil yaitu kualitas minyak yang dihasilkan secara fermentasi menggunakan $S$. cereviceae mempunyai nilai rendemen, kadar air, bilangan penyabunan, bilangan iodium yang lebih baik apabila dibandingkan dengan minyak yang dihasilkan secara tradisional (cara klentik). Berdasarkan uji organoleptik terhadap warna dan aroma, minyak yang dihasilkan secara fermentasi lebih disukai oleh panelis. Selain itu, kualitas minyak hasil fermentasi pada semua parameter, kecuali bilangan iodium, sesuai dengan standart yang ditetapkan oleh
Standar Industri Indonesia dan Departemen Perdagangan RI (1976).

Untuk penelitian lebih lanjut disarankan untuk membandingkan dengan inokulum dari species yang lain yang berpotensi dalam menghasilkan minyak secara fermentasi, misal menggunakan bakteri golongan asam laktat atau asetat yang tidak patogen.

\section{Daftar Pustaka}

Anonim, 1990. Statistik Perkebunan Indonesia Tahun 1990. Dirjen Perkebunan Republik Indonesia, Jakarta

Anonim, 2004. Kelapa untuk berdayakan Masyarakat Pesisir. http://kompas.com/kompascetak/0412/02/bahari/1412428.htm. download 16 Maret 2005

Anggraheni dan Dhalimi, A., 1993, Pembuatan Minyak Kelapa Secara Fermentasi di Daerah Pasang Surut, Bul. Littri. 5:54-56.

Buda, K., 1981, Kelapa dan Hasil Pengolahannya, Bag. Teknologi Hasil Pertanian, Fakultas Pertanian Universitas Udayana, Denpasar. 
Brock, T.D., Madigan, M.T., Martinko, J.M. and Parker, J. 1997, Biology of Microorganism, Prentice Hall International Inc, USA.

Crueger W. and Crueger, A. 1990, Biotechnology : A Textbook of Industrial Microbiology, Sinauer Associates Inc, Sunderland.

Eniq M., 2005. Characteristics of Virgin Coconut oil. http://www.tropicaltraditions.com/virgin_coc onut_oil.htm. download 19 Maret 2005

Fardiaz, S., 1992, Mikrobiologi Pangan I, PT. Gramedium Pustaka Utama, Jakarta.

Gill, J.V., Mateo, J.J., Jimenez, M., Pastor, A. and Huerta, T. 1996, Aroma compound in Wine as influence by apiculate Yeast, Journal of Food Science. 61 (6)

Gusmalini, Rahzarni, Desminarti, S. dan Evawati. 1997, Perbaikan Mutu Minyak Kilang Rakyat dengan Pemanfaatan Nira di dalam Proses Pengolahan, Prosiding Seminar Teknologi Pangan, Politeknik Pertanian, Universitas Andalas, Padang: 325-332.

Hamdan, H., 1991, Efek Pengolahan Minyak Kelapa Secara Peragian pada Beberapa Adonan Ragi Terpilih Terhadap Rendeman dan Mutu Minyak Kelapa, Pusat Penelitian Universitas Andalas, Padang

Ketaren, S. 1986. Peragian Lemak dalam Bahan Pangan. Departemen Teknologi Hasil Pertanian, Fakultas Teknologi dan Mekanisasi IPB, Bogor

Lloyd, C. 1997. Glycolysis Metabolic Pathway in Saccharomyces cereviceae. http://www.cellml.org/examples/repository/gl ycolysis_pathway_1977_doc.html. download 16 Maret 2005

Maria, E. 2005. Virgin Coconut oil. http://www.estermaria.com/vco3.htm, down load 16 September 2005
Muchtar, R., Ahmad,M. dan Sholfiadi,J. 1981, Pengembangan Sistem Fermentasi dalam Pengolahan Minyak Kelapa di Daerah Sumatera Barat, Proyek Peningkatan dan Pengembangan Perguruan Tinggi, Universitas Andalas, Padang.

Setiaji, B. dan Sasmita, J. 1987, Sistim Koloid pada Krim Santan Kelapa, Seminar Kajian Kimiawi Pangan dan Gizi, Universitas Gadjah Mada, Yogyakarta, 15-17 September 1987 : 223232.

Sibuea, P. 2004. Virgin Coconut Oil, penyembuh Ajaib dari Buah Kelapa. http://www.kimialipi.net/index.php?pilihan=berita\&id=2. download 16 Maret 2005

Simmons, K. 2005. Classification of the Sub-division Ascomycotina. http://io.uwinnipeg.ca/ simmons/2152web/21 52/fungi2a.htm. download 16 Maret 2005

Sudarmadji, S., Haryono, B., dan Suhardi. 1996. Prosedur Analisa untuk Bahan Makanan dan Pertanian, Liberty, Yogyakarta.

Suhardiman. 1994. Bertanam Kelapa Hibrida, Penebar Swadaya, Yogyakarta.

Swern, D. 1964, Bailey's Industrial Oil and Fat Product, Vol I, Intersciene Publisher, Sydney.

Tazar, N., Syahrul, S., dan Ermiati. 1998, Optimasi Lama Fermentasi dalam Proses Ekstraksi Minyak Kelapa dengan Ragi Tempe (Laporan Penelitian), Politeknik Pertanian Negeri Payakumbuh, Padang.

Tortora, G.J, Funke, B.R. and Case, C.L. 2001. Microbiology, An Introduction, 7th.ed., Addison Wesley Longman, Inc, Toronto

Yarrow, D. 1994. The Yeast, A Taxonomic Study, $3^{\text {rd }}$. ed, Elsevier Science Publishers B.V., Amsterdam 